\title{
NORDIC JOURNAL OF
}

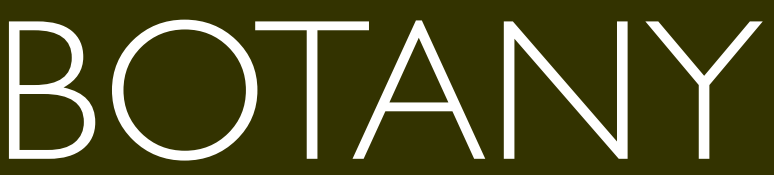

\section{Research}

\section{Cytotaxonomic investigations on Allium valdecallosum (Amaryllidaceae), a critical species endemic to Morocco}

\author{
Salvatore Brullo, Cristian Brullo, Salvatore Cambria and Cristina Salmeri
}

S. Brullo (http://orcid.org/0000-0003-2568-7278) (salvo.brullo@gmail.com), C. Brullo, S. Cambria, Dept of Biological, Geological and Environmental Sciences, Univ. of Catania, Italy. - C. Salmeri (http:/lorcid.org/0000-0002-5261-590X), Dept of Biological, Chemical and Pharmaceutical Sciences and Technologies (STEBICEF), Univ. of Palermo, Palermo, Italy.

\section{Nordic Journal of Botany}

2018: e02097

doi: $10.1111 / \mathrm{njb} .02097$

Subject Editor: Panayiotis Trigas Editor-in-Chief: Torbjörn Tyler Accepted 18 October 2018
Allium valdecallosum is a critical and poorly known species endemic to Morocco. Its diagnostic features, karyology, seed testa micro-morphology, leaf anatomy, ecology, distribution, conservation status, and taxonomic relationships are examined here.

Keywords: Mediterranean, taxonomy, karyology, Allioideae

\section{Introduction}

As a part of biosystematic studies on the species belonging to Allium subgen. Allium in the Mediterranean area (Brullo et al. 1997a, b, 1999, 2003, 2008a, b, 2010, 2014, 2017), a very critical species recorded from a single locality and not recently recollected had to be examined. The species was first described by Maire and Weiller (Maire 1940) from Morocco and named Allium valdecallosum, due to a callous thickening at the tepal base. The species is an obligated chasmophyte that grows in calcareous crevices of deep cliff-sided canyons in the Todra (or Todgha) Gorge (High Atlas Mountains), coinciding with its 'locus classicus', as well as in a newly discovered locality further south in the High Atlas, near Imi-n-Tala. Detailed morphological investigations carried out on living plants allowed us to conclude that $A$. valdecallosum is a well differentiated species, clearly distinct from $A$. paniculatum L. s.s., an east European element (Salmeri et al. 2016) of which it was regarded as synonym by Wilde-Duyfjes (1976) and Ibn Tattou (2001). Besides, A valdecallosum has no affinity with A. flavum L., which Maire and Weiller (Maire 1940) indicated as closely related to this species, probably just due to the tepal colour and the exserted stamens. Other authors instead treated $A$. valdecallosum as a valid species morphologically distinct from the other taxa of this genus occurring in the Mediterranean area, though without highlighting any taxonomic relationships (Vindt 1954, Maire 1958, Dobignard and Chatelain 2010, El Oualidi et al. 2012, Fennane 2014, Rankou et al. 2015, Lala et al. 2018). From the taxonomical viewpoint, $A$. valdecallosum shows closer relationships with other very rare or local Allium species endemic to scattered localities throughout the Mediterranean (Algeria, Morocco, Spain, Baleares and Sicily) such as A. seirotrichum Ducellier \& Maire, A. trichocnemis Gay, A. chrysonemum Stearn, A. reconditum Pastor,

(C) 2018 The Authors. Nordic Journal of Botany (C) 2018 Nordic Society Oikos 
Valdés \& Munoz, $A$. rouyi G. Gautier, $A$. grosii Font Quer, A. franciniae Brullo \& Pavone (Gay 1847, Rouy 1898, Ducellier and Maire 1922, Font Quer 1924, Stearn 1978, Brullo and Pavone 1983, Khedim et al. 2016). All these species share characters such as leaf sheaths partially covering the stem, inflorescence few-flowered and lax or sometimes dense with more flowers, two unequal spathe valves usually shorter than the umbel, stamen filaments flattened and widened below, the inner ones often uni-bicuspidate, ovary with well developed nectariferous pores, bordered by a membranous plica, very conspicuous even in the capsule. The present study aims to clarify the taxonomic position and relationships of $A$. valdecallosum, through morphological, karyological and anatomical investigations carried out on living plants collected from the two known localities of the species.

\section{Material and methods}

The study was carried out on living material of Allium valdecallosum collected from the two known Moroccan localities (Todra Gorge and Imi-n-Tala), and cultivated in the Botanical Garden of Catania. Voucher specimens are deposited in herbarium CAT.

Qualitative and quantitative morphological features were measured and scored on fresh material (five individuals), using a Zeiss Stemi SV11 Apo stereomicroscope at 6-66x magnification.

Leaf anatomy was studied on cultivated plants, using green leaf blades of maximum size in their optimal vegetative development. Leaf cross-sections were fixed in Carnoy (6:3:1 $\mathrm{v} / \mathrm{v} / \mathrm{v}$ absolute ethanol:chloroform:glacial acetic acid), and embedded in paraffin; the transverse sections (about $10 \mu \mathrm{m}$ thick) were doubled stained with ruthenium red and light green.

Karyological analyses were performed on mitotic plates from root tip cells of cultivated bulbs, pre-treated for $3 \mathrm{~h}$ at room temperature with a $0.3 \%(\mathrm{w} / \mathrm{v})$ colchicine water solution, fixed in Farmer's fixative (3:1 v/v, absolute ethanol: glacial acetic acid) for $12 \mathrm{~h}$ and stored in $70 \%$ ethanol. Then, root tips were hydrolyzed in $1 \mathrm{~N} \mathrm{HCl}$ for $7 \mathrm{~min}$ at $60^{\circ} \mathrm{C}$ and stained according to the Feulgen technique. Microphotographs of 10 good metaphase plates from different individuals were taken using a Zeiss Axioskop 2 microscope equipped with a monochrome CCD camera and an AxioCam MRc5 high-resolution digital camera. Chromosome measures and karyotype features were estimated following Brullo et al. (2014).

Seed micromorphology was studied on mature seeds of cultivated plants using micrographs obtained under a Zeiss EVO LS 10 scanning electron microscope (SEM). Five dried seeds were directly mounted onto aluminium stubs with double adhesive tape and coated with gold prior to observation. The terminology used for describing the seed coat sculpturing follows Barthlott (1981) and Gontcharova et al. (2009).

\section{Results}

Our investigations revealed that the populations of Allium valdecallosum are morphologically distinct from all related Mediterranean species. In order to highlight its morphological, karyological, anatomical and ecological features, the following taxonomic treatment is provided:

\section{Allium valdecallosum Maire \& Weiller (in Maire 1940, p. 43) Fig. 1}

Type: Iter Maroccanum XXIX. In rupestribus calcareis faucium amnis Todgha Atlantis Majoris, 1500 m a.s.l., 23 Jun 1939, R. Maire and M. Weiller 464 (Lectotype: MPU 3230!, designated by Wilde-Duyfjes 1976). <https://plants. jstor.org/stable/10.5555/al.ap.specimen.mpu004273>.

\section{Description}

Bulb ovoid-ellipsoid to ellipsoid, 15-20 × 7-12 mm, with outer tunics fibrous, brownish, and inner ones membranaceous, whitish. Stem $12-35 \mathrm{~cm}$ tall, cylindrical, green, glabrous, erect, covered by leaf sheaths up to $1 / 2$ of total length. Leaves 4, green, hairy on the sheaths and at the base of the blade, with hairs $0.5-2.5 \mathrm{~mm}$ long; blade $15-28 \mathrm{~cm}$ long, $1.5-3.0 \mathrm{~mm}$ wide, subcylindrical, fistulous, with 2 ventral ribs. Spathe persistent, with two unequal, opposite, erect valves, much shorter than the inflorescence, shortly beaked, the larger 5-8-nerved and 8-20 mm long, the smaller 3-6-nerved and 7-15 mm long. Inflorescence lax, 5-25(-50)-flowered; pedicels unequal, 8-30 mm long, erect to slightly curved at anthesis. Perigon campanulate, with tepals sub-equal, oblong to ovate, obtuse at apex, with a basal callous thickening, greenish-yellow, dorsally pruinose, 5.0-6.5 $\mathrm{mm}$ long, $2.5-3.2 \mathrm{~mm}$ wide, with green midrib. Stamens exserted from the perigon, with filaments unequal, yellowish, (3.5-)4.0-6.2 $\mathrm{mm}$ long, the outer ones simple, the inner ones with 1 or 2 cusps at the base, connate below into an annulus ca. $1 \mathrm{~mm}$ high; anthers yellow, oblong, $2.0-2.4 \times 0.8-0.9 \mathrm{~mm}$, rounded at apex. Ovary subglobose, yellow-green, slightly papillose in the upper part, $2.2-2.5 \times 2.3-2.5 \mathrm{~mm}$, with well-developed nectariferous pores bordered by a membranous plica; style yellowishwhite below, 1.8-2.0 $\mathrm{mm}$ long, extending up to $5 \mathrm{~mm}$ after fertilization. Capsule trivalved, subglobose, greenish, $5.0-5.5 \times 5.5-6.0 \mathrm{~mm}$.

\section{Phenology}

Flowering in May-June; fruiting in June.

\section{Distribution and habitat}

Based on literature (Maire 1958, Fennane and Ibn Tattou 1998, 2008, Rankou et al. 2013, 2015), Allium valdecallosum is a very rare species, hitherto known only from Todra gorge (Morocco), where it grows in the rocky crevices of amazing vertical walls made up from Bathonian limestones and dated back to the Jurassic. However, the species has also been found at a new site in the High Atlas, in a valley near 


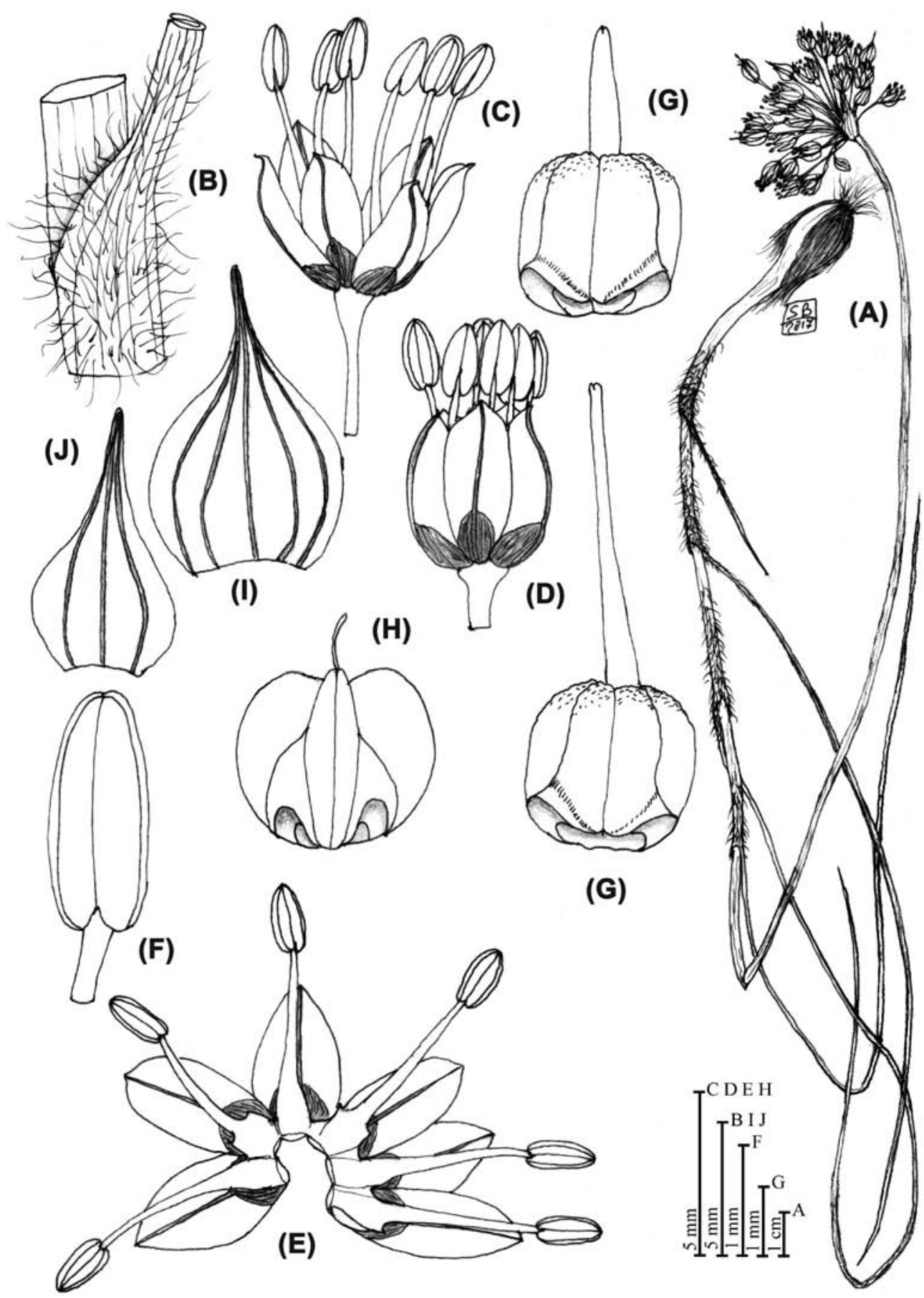

Figure 1. Diagnostic features of Allium valdecallosum. (A) habit, (B) leaf indumentum, (C) open flower, (D) closed flower, (E) perigone and stamens open, $(\mathrm{F})$ anther, $(\mathrm{G})$ ovaries, $(\mathrm{H})$ capsule, (I) larger spathe valves, (J) smaller spathe valves. Illustration by $\mathrm{S}$. Brullo based on living material coming from the type locality.

Imi-n-Tala, located south of Marrakech (Fig. 2). In both places, $A$. valdecallosum grows on limestone at around $1500 \mathrm{~m}$ a.s.l., within a mountain belt characterized by a thermo-Mediterranean arid bioclimate, where it is member of a chasmophilous vegetation, usually quite scattered and floristically very poor.

\section{Additional specimens examined}

Morocco, High Atlas: Gorges de Todra. 2 Jun 1994, S. Brullo and P. Signorello s.n. (CAT); near Imi-n-Tala, ca $1500 \mathrm{~m}$ a.s.l., 24 Jun 2016, S. Cambria s.n. (CAT); ibid, cultivated in Botanical Garden of Catania, 30 May 2018, S. Brullo and S. Cambria s.n. (CAT). 


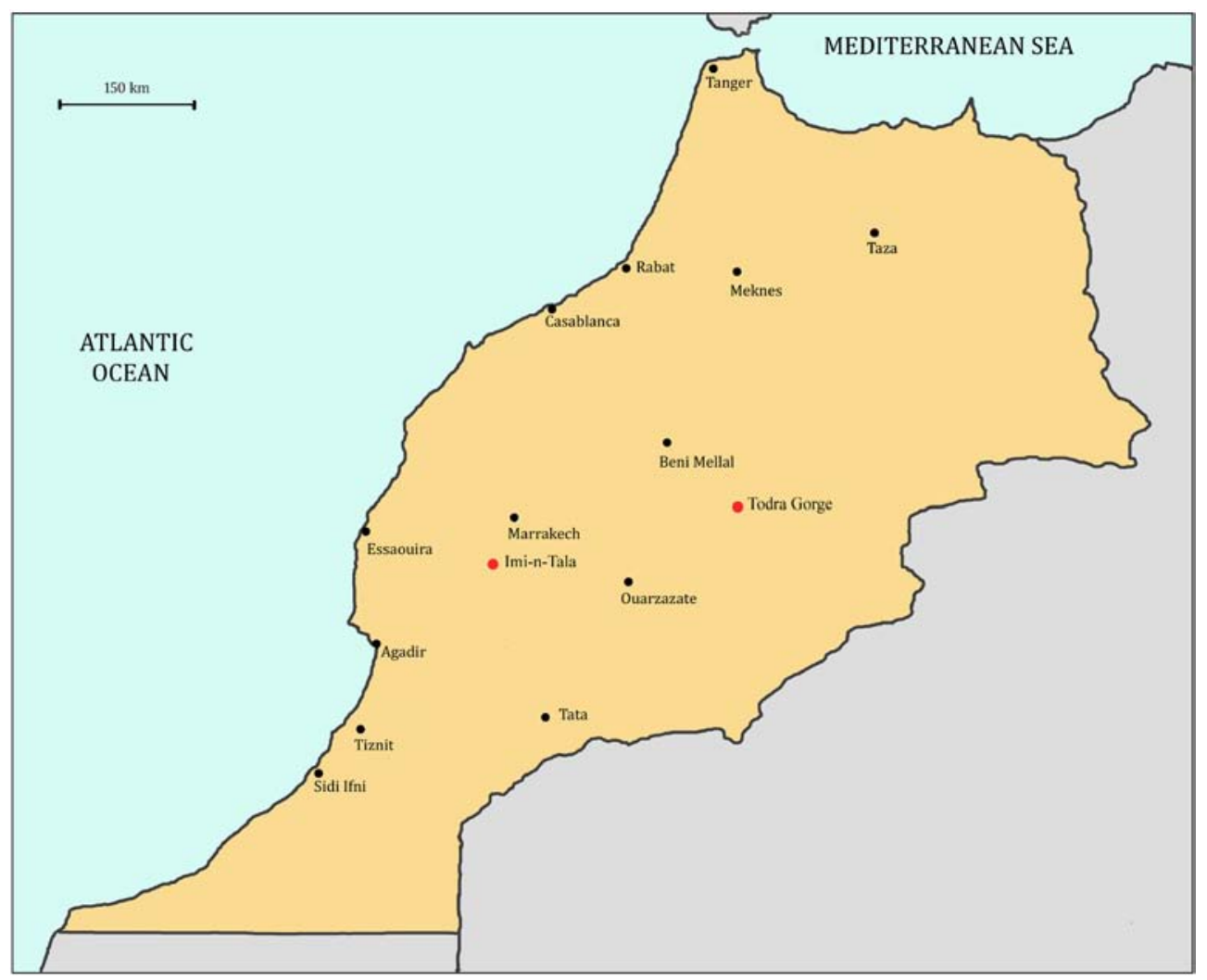

Figure 2. Geographic distribution map of Allium valdecallosum.

\section{Leaf anatomy}

The leaf cross section of Allium valdecallosum shows a smooth sub-elliptical outline, except for two ventral ribs which demarcate a furrow longitudinally running through the leaf blade. The epidermis is formed by small cells covered by a well-developed and finely denticulate cuticle. There are numerous unicellular hairs, each inserted in a large basal cell. The stomata are numerous and distributed along the whole leaf perimeter. The palisade tissue is regular and compact, arranged in one layer of long cylindrical cells. The spongy tissue is compact and limited to the peripheral part, where many secretory canals occur, while the leaf is fistulous in the centre. Seven big vascular bundles occur in correspondence of the adaxial surface, while lengthwise on the abaxial face one big central vascular bundle is flanked ones on each side by three smaller (Fig. 3).

\section{Karyology}

The chromosome complement of Allium valdecallosum is here studied for the first time. The somatic chromosome number is tetraploid with $2 \mathrm{n}=32$ (Fig. 4A). This species shows a diploidized karyotype with a clear pairing behaviour of its chromosomes. In fact, all studied mitotic metaphase plates revealed the occurrence of 16 distinct chromosome pairs, of which 9 were metacentric, 3 meta-submetacentric (with arm ratio more than 1.3), 2 typical submetacentric and 2 subtelocentric, the latter ones microsatellited on the short arms (Fig. 4B). Thus, the chromosome formula can be specified as: $2 n=4 x=32: 18 m+6 m s m+4 s m+4 s t^{\text {sat }}$. The absolute chromosome length of the $A$. valdecallosum chromosomes ranged from $12.6 \pm 07 \mu \mathrm{m}$ of the longest metacentric pair to $7.31 \pm 0.3 \mu \mathrm{m}$ of the shortest subtelocentric one, with a mean chromosome length of $9.6 \pm 1.5 \mu \mathrm{m}$, while the relative length varied from $4.3 \% \pm 0.1$ to $4.20 \% \pm 0.06$. Overall, as stated by several karyomorphometric parameters (Table 1), the karyotype of $A$. valdecallosum is homogeneous with morphologically regular chromosomes.

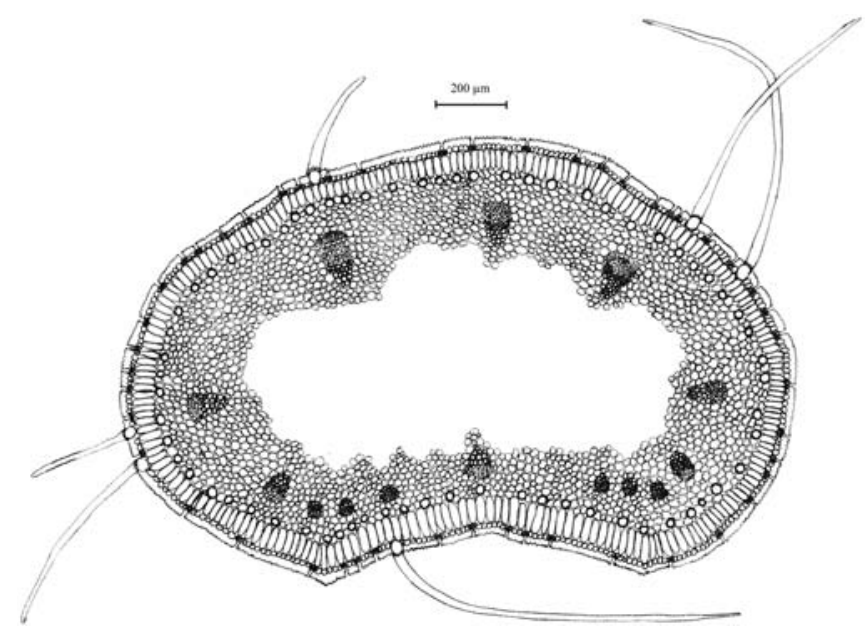

Figure 3. Leaf cross section of Allium valdecallosum from living material coming from the type locality. 


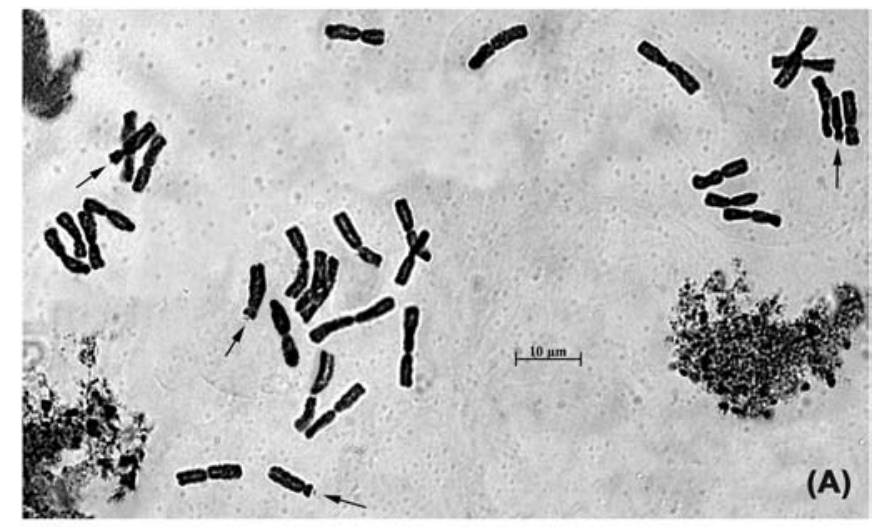

||⿴囗⿱一一⿻口卄.

$10 \mu \mathrm{m}$

(B)

Figure 4. Chromosome complement $(2 \mathrm{n}=4 \mathrm{x}=32)$ of Allium valdecallosum from type locality. (A) mitotic metaphase plate, arrows indicate satellite chromosomes, (B) ideogram.

\section{Seed morphology and testa microsculpturing}

According to literature data (Pastor 1981, Češmedžiev and Terzijski 1997, Fritsch et al. 2006, Neshati and Fritsch 2009, Celep et al. 2012, Salmeri et al. 2016, Lin and Tan
2017, Özhatay et al. 2018), the micro-sculptures of the seed testa in Allium species are a stable and conservative character, which have relevant taxonomical and phylogenetic implications. Seeds of Allium valdecallosum show a semi-ovoid shape $(3.3 \times 2.0-2.2 \mathrm{~mm})$, with a feebly rugose surface (Fig. 5A-B). Observations under SEM at high magnification $(250 \times$ and $500 \times)$ revealed irregularly polygonate testa cells, 45-89 $\mu \mathrm{m}$ long (Fig. 5C-F). The anticlinal walls appear flat, rather straight, and partly covered by strip-like sculptures forming a widened intercellular region, which is partially lacerate. The periclinal walls are flat, with some granulose verrucae arranged in one or two rows. Overall, these micromorphological features of the seed testa are rather common among several other species of Allium subgen. Allium.

\section{Conservation status}

Based on our observations at the two sites where Allium valdecallosum was found, its populations are represented by an exiguous number (no more than 100) of mature individuals, distributed in an area of just a few $\mathrm{km}^{2}$. Although they often grow in quite inaccessible rupestrian sites (Fig. 6), which can be reached only by reckless climbers, following the IUCN criteria (IUCN 2014), A. valdecallosum must be considered a 'Critically endangered' species (CR, B1ab ii, iii, v+2ab ii, iii, v), as already proposed by Rankou et al. (2015).

\section{Taxonomic relationships}

For a set of significant morphological features, Allium valdecallosum falls within a group of species belonging to

Table 1. Karyomorphometric parameters and symmetry indices for Allium valdecallosum. Mean values calculated from 10 good metaphase plates from individuals from the type localities. Abbreviations: $\mathrm{LA}=$ long arm; $\mathrm{SA}=$ short arm; $\mathrm{TAL}=$ total absolute length; $\mathrm{TRL}=$ total relative length; $\mathrm{AR}=$ arm ratio; $\mathrm{Cl}=$ centromeric index; $\mathrm{CA}=$ centromeric asimmetry; Type $=$ chromosome nomenclature; sat $=$ satellited; $\mathrm{TCL}=$ total chromosome length; $M C L=$ mean chromosome length; $d$-value=difference between long arms and short arms; $D R L \%=$ difference of rela-

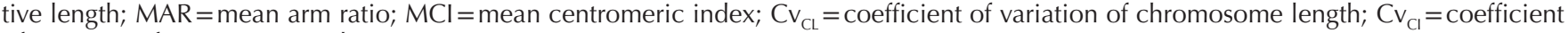
of variation of centromeric index; $\mathrm{MCA}=$ mean centromeric asymmetry.

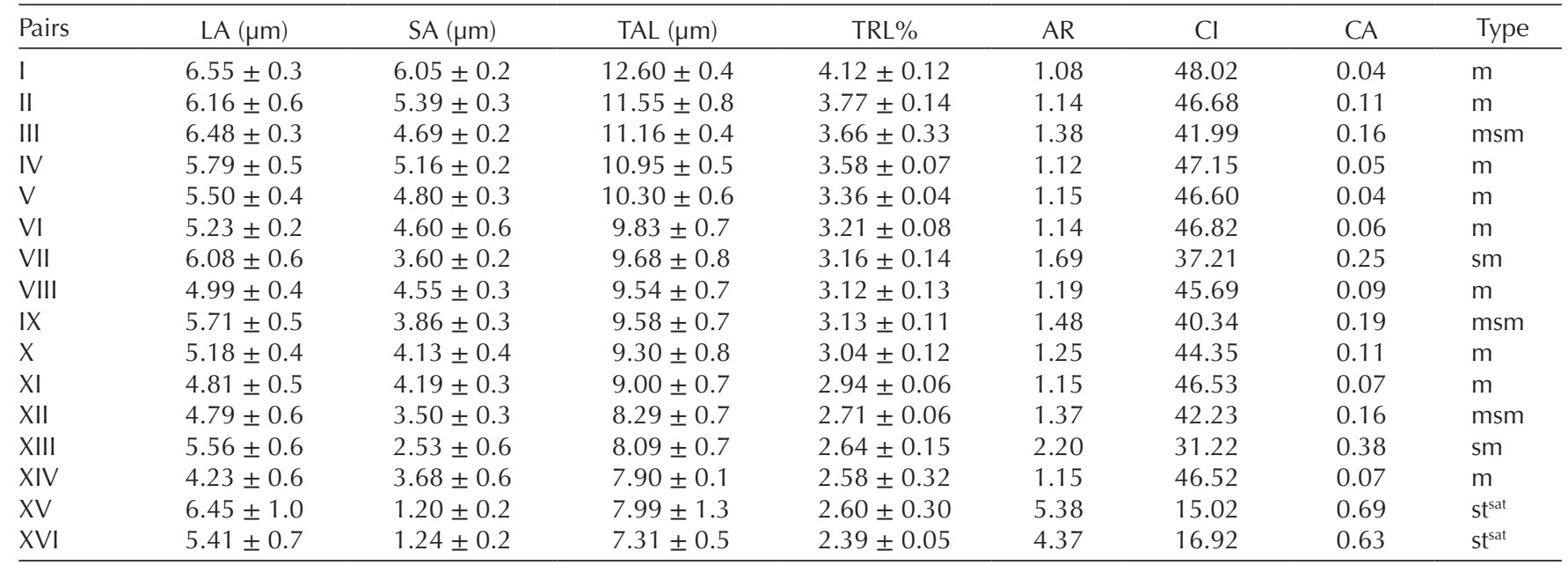

TCL: $306.10 \pm 18.06 \mu \mathrm{m}$; MCL: $9.57 \pm 1.5 \mu \mathrm{m}$; d-value: 49.80; DRL\%: 1.95; S\%: 54.49; MAR: 1.41; MCl: 44.35; $\mathrm{Cv}_{\mathrm{CL}}$ : 15.45; Cv ${ }_{\mathrm{Cl}}$ 8.66; $M_{C A}: 19.05$. 

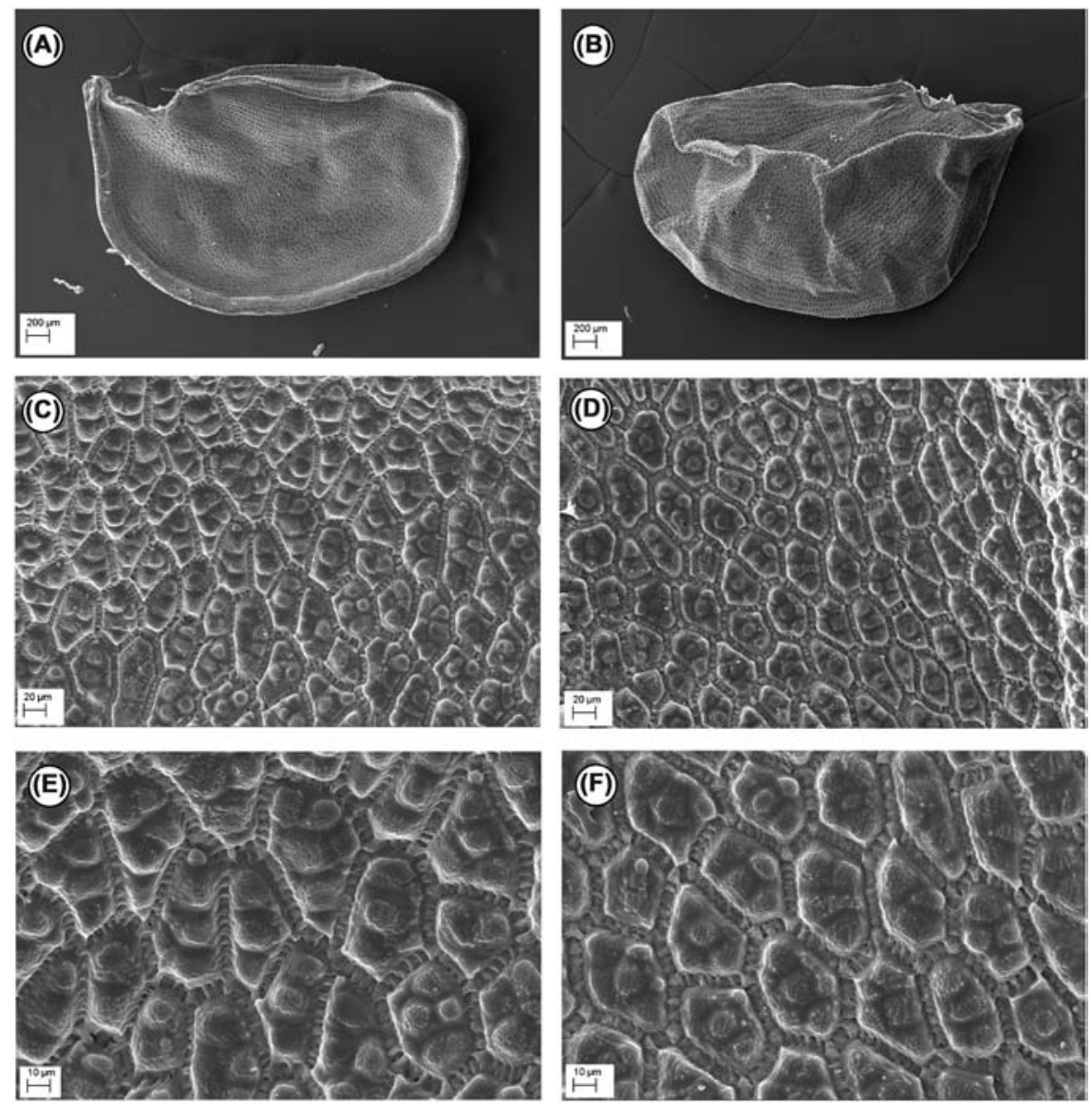

Figure 5. SEM micrographs of Allium valdecallosum seed coat. (A) ventral face $25 \times$, (B) dorsal face $25 \times$, (C) exotesta at central part of ventral face $250 \times$, (D) exotesta at central part of dorsal face $250 \times$, (E) detail of testa cells from ventral face $500 \times$, (F) detail of testa cells from dorsal face $500 \times$. Photos from material coming from the type localities (CAT).

A. subgen. Allium, which in the past were gathered in the sect. Scorodon s.l. As previously highlighted, A. valdecallosum shows close affinities with other rare species occurring in various Mediterranean countries and in particular with $A$. chrysonemum and $A$. rouyi, both species currently known from few stands in south Spain (Stearn 1978, Pastor and Valdes 1983, Ruiz Rejon et al. 1986, Cabezudo et al. 1992, Pastor and Diosdado 1995). These two species are quite similar in having leaves that are very long, subcylindrical, fistulous and canaliculate, hairy on the sheath and blade base, spathe valves much shorter than the inflorescence, perigon campanulate, greenish-yellow, 5.0-6.5 mm long, stamen filaments yellowish, anthers yellow and ovary yellow-green with welldeveloped nectariferous pores. Similarly to $A$. valdecallosum, A. chrysonemum is characterized by a tetraploid chromosome complement with $2 \mathrm{n}=4 \mathrm{x}=32$ (Stearn 1978, Ruiz Rejon et al. 1986), while $A$. rouyi is diploid with $2 \mathrm{n}=2 \mathrm{x}=16$ (Pastor and Diosdado 1995). However, $A$. chrysonemum differs from $A$. valdecallosum in the leaf indumentum with more scattered hairs, tepals not thickened at the base and narrower, inner stamen filaments without cusps, annulus narrower, and anthers and capsule shorter, while $A$. rouyi diverges in having very scattered leaf indumentum (sometimes subglabrous), thinner blade (0.5-1.0 mm wide), fastigiate umbel, tepals not thickened at the base and narrower, inner stamen filaments without cusps, not exserted from the perigon, and shorter anthers and capsule. Other species somewhat related to $A$. valdecallosum sharing hairy leaves, usually shorter spathe valves, lax umbel with divaricate pedicels, inner stamen filaments with 2 short cusps and ovary with well-developed nectariferous pores are A. trichocnemis and A. seirotrichum, which also are tetraploid with a chromosome complement $2 n=4 x=32$ (Khedim et al. 2016). The first one is only known from two localities, in Algeria and Morocco (Maire 1958, Fennane and Ibn Tattou 1998, Khedim et al. 2016), while the second species is confined to a single stand in Algeria (Maire 1958, Khedim et al. 2016). However, some relevant morphological features differentiate these two species from $A$. valdecallosum, since $A$. trichocnemis is characterized by stem up to $60 \mathrm{~cm}$ tall, spathe valves slightly shorter than umbel (sometimes subequal), perigon cylindrical-urceolate, tepals pink-lilac with purple midrib, stamens included, with filaments $1.3-3.0 \mathrm{~mm}$ long, the inner ones with two cusps in the middle part, while $A$. seirotrichum has leaf blade hairy almost thruoghout, spathe valves slightly shorter than umbel (sometimes subequal), perigon cup-shaped, tepals white, 

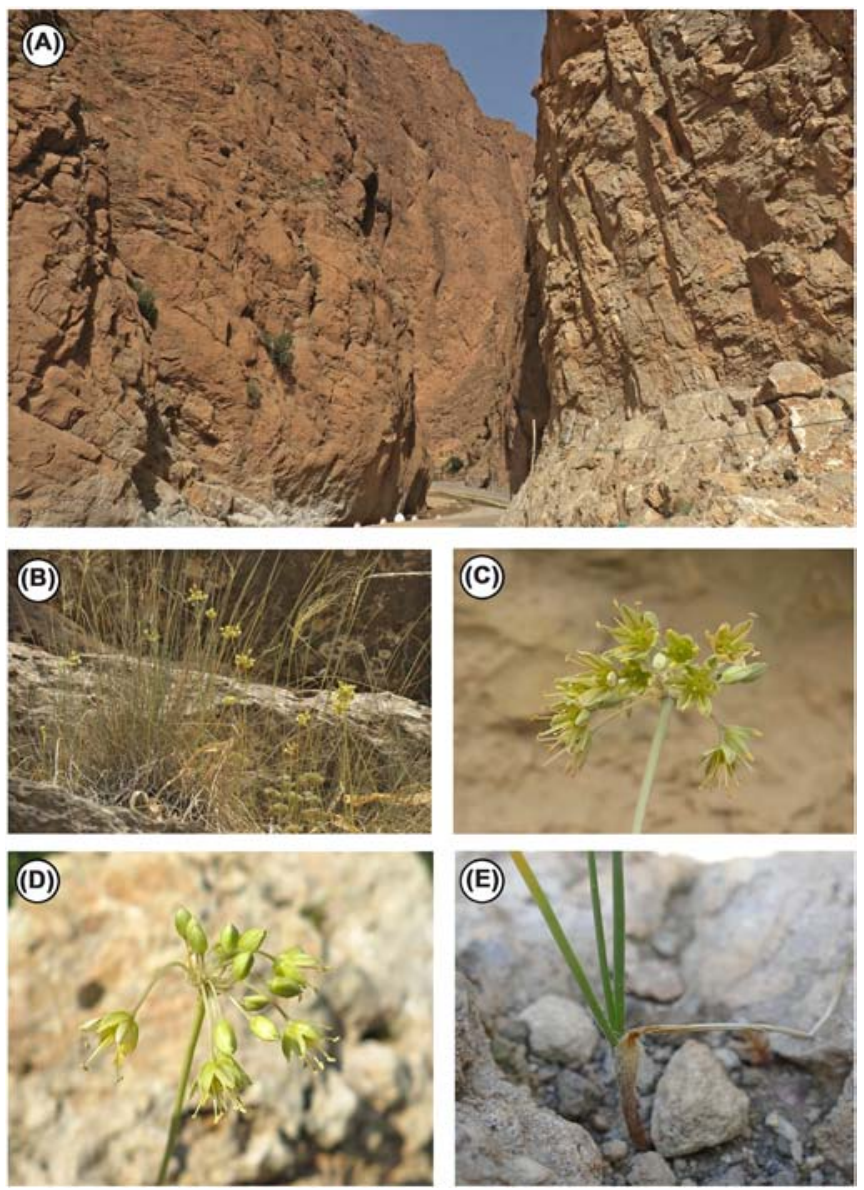

Figure 6. Phenological features of Allium valdecallosum. (A) growth habitat in Todra Gorge (Morocco), (B) individuals of $A$. valdecallosum in the valley near Imi-n-Tala (Morocco), (C) inflorescence detail of $A$. valdecallosum from Imi-n-Tala, (D) inflorescence detail of $A$. valdecallosum, cultivated specimen coming from Todra Gorge, (E) leaf detail of $A$. valdecallosum, cultivated specimen coming from Todra Gorge. Photos by S. Cambria.

about $8 \mathrm{~mm}$ long, and stamens included with filaments 3.9$4.2 \mathrm{~mm}$ long, the inner ones with two cusps in the middle part. Moreover, $A$. valdecallosum shows some morphological affinities with other geographically isolated species, such as $A$. reconditum from south Spain (Pastor and Valdes 1983, Pastor 1985), A. grosii from Ibiza in the Balearic Islands (Font Quer 1924, Pastor and Valdes 1983, Brullo et al. 1992, Aedo 2013) and $A$. franciniae from Marettimo islet near Sicily (Brullo and Pavone 1983). Aedo (2013) however considered $A$. reconditum, as well as $A$. chrysonemum, as synonyms of $A$. rouyi, though $A$. reconditum differs in its hexaploid $(2 \mathrm{n}=6 \mathrm{x}=48)$ chromosome complement (Pastor 1985), the occurrence of 2-3 leaves and pale pink tepals with a pink midrib. Allium grosii is another hexaploid species (Brullo et al. 1992, Castro and Rosselló 2005) like $A$. reconditum, differentiating from A. valdecallosum and the other species of this group in having a flat leaf blade, cylindrical and slightly urceolate perigon up to $8 \mathrm{~mm}$ long, pink-purplish tepals with dark purplish midrib, very short yellow-purplish stamen filaments, $1-2 \mathrm{~mm}$ long, purplish-pink anthers and ovary with less developed nectariferous pores. Allium franciniae also has some significant features in common with $A$. valdecallosum, regarding the outer bulb tunics, spathe valves and ovary, as well as the ecology, but it is morphologically more similar to A. grosii with glabrous leaves, very small and 3-5-nerved spathe valves, cylindrical and slightly urceolate perigon, stamens included, and ovary with less developed nectariferous pores; in addition both species are characterized by bulbilliferous bulbs and grow in the rocky crevices (Brullo et al. 1992). Nevertheless, $A$. franciniae is differentiated from $A$. grosii in having more slender and flexuous stems, 4 bostryces, pinkish-white and linear tepals, longer stamen filaments $(2.5-3.0 \mathrm{~mm})$, yellow anthers, and shorter ovary and capsule.

As far as the taxonomic relationships are concerned, A. valdecallosum cannot be included in $A$. sect. Codonoprasum Rchb. (in Mössler 1827) due to its ovary with well-developed nectariferous pores, bordered by a membranous plica, and lateral teeth at the base of the inner stamen filaments. According to Wendelbo (1971) and Stearn (1978, 1980), based on these features this species should instead be included in A. sect. Scorodon Koch. However, many molecular studies (Fritsch and Friesen 2002, Friesen et al. 2006, Nguyen et al. 2008, Li et al. 2010, Hirschergger et al. 2010) have pointed out that the traditional $A$. sect. Scorodon s.l. is actually an assemblage of various and well differentiated phylogenetic lineages. Based on the above-mentioned literature data, $A$. sect. Scorodon s.str. is typified by $A$. moschatum L., which is now included in $A$. subgen. Polyprason Radić rather than in A. subgen. Allium. Conversely, many other species previously included in this section have been retained in $A$. subgen. Allium but transferred to other sections (Khassanov 2000, Fritsch and Friesen 2002, Friesen et al. 2006, Khassanov et al. 2011). Therefore, for now we considered appropriate not to attribute $A$. valdecallosum to any known section $A$. subgen. Allium, deferring its correct taxonomic treatment when results from a phylogenetic study on this species and its allies, currently in progress, will be available.

\section{References}

Aedo, C. 2013. Allium L. - In: Rico, E. et al. (eds), Flora Iberica. Vol. 20. - Real Jardin Botanico, CSIC, Madrid, pp. 220-273.

Barthlott, W. 1981. Epidermal and seed surface characters of plants: systematic applicability and some evolutionary aspect. - Nord. J. Bot. 1: 345-355.

Brullo, C. et al. 2010. Allium makrianum (Alliaceae), a new autumnal species from Greece. - Phyton (Horn) 49: 267-278.

Brullo, C. et al. 2014. Allium therinanthum (Amaryllidaceae), a new species from Israel. - Phytotaxa 164: 29-40.

Brullo, C. et al. 2017. Allium nazarenum (Amaryllidaceae), a new species of the section Codonoprasum from Israel. - Phytotaxa 327: 237-251.

Brullo, S. and Pavone, P. 1983. Allium franciniae, specie nuova dell'Isola di Marettimo (Arcipelago delle Egadi). - Webbia 37: 11-22. 
Brullo, S. et al. 1992. Cytotaxonomical notes on Allium grosii Font Quer from Ibiza (Balearic Islands). - Candollea 47: 77-81.

Brullo, S. et al. 1997a. Allium oporinanthum (Alliaceae), a new species from NW Mediterranean area. - Anal. Jard. Bot. Madrid 55: 297-302.

Brullo, S. et al. 1997b. Allium anzalonei, eine neue Art für die italienische Flora. - Sendtnera 4: 33-39.

Brullo, S. et al. 1999. Allium archeotrichon (Alliaceae), a new species from Rhodos (Dodekannisos, Greece). - Nord. J. Bot. 19: 41-46.

Brullo, S. et al. 2003. Three new species of Allium Sect. Codonoprasum from Greece. - Plant Biosyst. 137: 131-140.

Brullo, S. et al. 2008a. Allium aeginiense Brullo, Giusso \& Terrasi (Alliaceae), a new species from Greece. - Candollea 63: 197-203.

Brullo, S. et al. 2008b. Taxonomic study on Allium dentiferum Webb \& Berthel. (Alliaceae) and its taxonomic relations with allied species from the Mediterranean. - Taxon 57: 243-253.

Cabezudo, B. et al. 1992. Observaciones sobre Allium rouyi Gautier. - Acta Bot. Malac. 17: 123-126.

Castro, M. and Rosselló, J.A. 2005. Chromosome numbers in plant taxa endemic to the Balearic Islands. - Bot. J. Linn. Soc. 148: 219-228.

Celep, F. et al. 2012. Taxonomic importance of seed morphology in Allium (Amaryllidaceae). - Syst. Bot. 37: 893-912.

Češmedžiev, I. and Terzijski, D. 1997. A scanning electron microscopic study of the spermoderm in Allium subg. Codonoprasum (Alliaceae). - Bocconea 5: 755-758.

Dobignard, A. and Chatelain, C. 2010. Index synonymique de la flore d'Afrique du Nord. Vol. 1: Pteridophyta, Gymnospermae, Monocotyledonae. - Édit. Conserv. Jard. Bot., Genève.

Ducellier, L. and Maire, R. 1922. Un Allium nouveau de la flore algérienne. - Bull. Soc. Hist. Nat. Afr. Nord 13: 22-23.

El Oualidi, J. et al. 2012. Checklist des endémiques et spécimens types de la flore vasculaire de l'Afrique du Nord. - Doc. Inst. Scient., Rabat 25: 1-189.

Fennane, M. 2014. Allium L. - In: Fennane, M. et al. (eds), Flore Pratique du Maroc. Vol. 3. - Trav. Inst. Scient. Rabat, Sér. Bot. 40: 398-409.

Fennane, M. and Ibn Tattou, M. 1998. Catalogues des plantes vasculaires rares, menacées ou endemiques du Maroc. - Bocconea 8: 5-243.

Fennane, M. and Ibn Tattou, M. 2008. Flore vasculaire du Maroc inventaire et chorologie. Vol. 2. - Trav. Inst. Scient., Sér. Bot. 39: 1-309.

Font Quer, P. 1924. De Alliis ebusitanis. - Butl. Inst. Catal. Hist. Nat., 2nd ser. 4: 143-146.

Friesen, N. et al. 2006. Phylogeny and new intrageneric classification of Allium L. (Alliaceae) based on nuclear rDNA ITS sequences. - Aliso 22: 372-395.

Fritsch, R. M. and Friesen, N. 2002. Evolution, domestication, and taxonomy. - In: Rabinowitch, H. D. and Currah, L. (eds), Allium crop science: recent advances. - CABI Publishing, pp. 5-30.

Fritsch, R. M. et al. 2006. Testa sculptures in Allium L. subg. Melanocrommyum (Webb. \& Berthel.) Rouy (Alliaceae). - Feddes Rep. 117: 250-263.

Gay, J. E. 1847. Allii species octo, pleraeque Algeriense. - Ann. Sci. Nat. Bot. sèr. 3: 195-223.

Gontcharova, S. B. et al. 2009. Seed surface morphology in some representatives of the genus Rhodiola sect. Rhodiola (Crassulaceae) in the Russian Far East. - Flora 204: 17-24.
Hirschergger, P. et al. 2010. Origins of Allium ampeloprasum horticultural groups and a molecular phylogeny of the section Allium (Allium: Alliaceae). - Mol. Phylogenet. Evol. 54: 488-497.

Ibn Tattou, M. 2001. Contribuciones a la flora vascular de Marruecos (3-5). - Acta Bot. Malac. 26: 287-303.

IUCN 2014. Guidelines for Using the IUCN Red List Categories and Criteria. Ver. 11. Prepared by the Standards and Petitions. - $\quad$ <http://jr.iucnredlist.org/documents/RedListGuidelines. pdf $>$, accessed 10 Oct 2014.

Khassanov, F. O. 2000. Subinfrageneric grouping in genus Allium L. subgenus Allium. - In: Ashurmetov, O. et al. (eds), Proc. of Plant Life in Southwest and Central Asia. 5th Int. Symp. Tashkent 1998. - Chinor Enk Tashkent, pp. 107-112.

Khassanov, F. O. et al. 2011. Taxonomic revision of Allium L. sect. Allium s. 1. in Central Asia. - Stapfia 95: 171-174.

Khedim, T. et al. 2016. Morphological and cytotaxonomic data of Allium trichocnemis and A. seirotrichum (Amaryllidcae) endemic to northern Algeria, compared with $A$. cupanii group. - Phytotaxa 243: 247-259.

Lala, S. et al. 2018. Towards the conservation of crop wild relative diversity in North Africa: checklist, prioritisation an inventory. - Genet. Resour. Crop Evol. 65: 113-124.

Li, Q. Q. et al. 2010. Phylogeny and biogeography of Allium (Amaryllidaceae: Allieae) based on nuclear ribosomal internal transcribed spacer and chloroplast rps16 sequences, focusing on the inclusion of species endemic to China. - Ann. Bot. 106: 709-733.

Lin, C.-Y. and Tan, D.-Y. 2017. Seed testa micromorphology of thirty-eight species of Allium (Amaryllidaceae) from central Asia, and its taxonomic implications. - Nord. J. Bot. 35: 189-200.

Maire, R. 1940. Contributions à l'étude de la flore de l'Afrique du Nord. - Bull. Soc. Hist. Nat. Afr. Nord 31: 7-49.

Maire, R. 1958. Flore de l'Afrique du Nord. Vol. 5. - Encycl. Biol. 54: 1-307.

Mössler, J. C. 1827. Gemeinnütziges Handbuch. Ed. 2, 1. - J. F. Hamerrich, Altona.

Neshati, F. and Fritsch, R. M. 2009. Seed characters and testa sculptures of some Iranian Allium L. species (Alliaceae). - Feddes Rep. 120: 322-332.

Nguyen, N. H. et al. 2008. A molecular phylogeny of the wild onions (Allium; Alliaceae) with a focus on the western North American center of diversity. - Mol. Phylogenet. Evol. 47: 1157-1172.

Özhatay, N. et al. 2018. Allium istanbulense, a new autumnal species of $A$. sect. Codonoprasum (Amaryllidaceae) from Turkey and its taxonomic position among allied species. - Phytotaxa 334: 152-166.

Pastor, J. 1981. Contribuciòn al estudio de las semillas de las especies de Allium de la Peninsula Ibèricae islas Baleares. - Lagascalia 10: 207-216.

Pastor, J. 1985. Karyology of Allium stearnii and A.reconditum, two new species from the Iberian Peninsula. - Phyton (Horn) 25: 73-76.

Pastor, J. and Valdes, B. 1983. Revision del genero Allium (Liliaceae) en la Peninsula Iberica e Islas Baleares. - Imprenta Sevillana, Sevilla.

Pastor, J. E. and Diosdado, J. C. 1995. A karyological study of Allium rouyi Gautier (Liliaceae), a recently rediscovered endemic species from the south of Spain. - Bot. J. Linn. Soc. 117: 255-258. 
Rankou, H. et al. 2013. The endemic flora of Morocco. - Phytotaxa 78: 1-69.

Rankou, H. et al. 2015. Conservation assessments and Red Listing of the endemic Moroccan flora (Monocotyledons). - Bot. J. Linn. Soc. 177: 504-575.

Rouy, G. 1898. Illustrationes Plantarum Europae rariorum, vol. 10. - Fils d'Emile Deyrolle, Paris, pp. 75-82.

Ruiz Rejon, C. et al. 1986. Numeros chromosomicos para la flora Española. 479-484. - Lagascalia 14: 292-297.

Salmeri, C. et al. 2016. What is Allium paniculatum L.? Establishing taxonomic and molecular phylogenetic relationships within A. sect. Codonoprasum Rchb. - J. Syst. Evol. 54: 123-135.
Stearn, W. T. 1978. European species of Allium and allied genera of Alliaceae: a synonymic enumeration. - Ann. Mus. Gouland. 4: 83-198.

Stearn, W. T. 1980. Allium L. - In: Tutin, T. G. et al (eds), Flora Europaea. Vol. 5. - Cambridge Univ. Press, pp. 49-69.

Vindt, J. 1954. Synopsis du genre Allium L. au Maroc. - Bull. Soc. Sci. Nat. Phys. Maroc 33: 109-128.

Wendelbo, P. 1971. Alliaceae L. - In: Rechinger, K. H. (ed.), Flora Iranica. Vol. 76. - Akademische Druck und Verlagsanstalt, pp. 1-100.

Wilde-Duyfjes, B. E. E. de 1976. A revision of the genus Allium in Africa. - Meded. Landb. Wageningen 76: 1-237. 